\title{
On Philipson's early-start and the maximum-exposure fallacies: A case study of selected 100 level students of the university of Ibadan
}

\author{
Ajayi Temitope Michael \\ Department of Linguistics and African Languages, University of Ibadan, Nigeria \\ Email address: \\ michealtemitope@yahoo.com, ajayi.temitope@dlc.ui.edu.ng
}

To cite this article:

Ajayi Temitope Michael. On Philipson's Early-Start and the Maximum-Exposure Fallacies: A Case Study of Selected 100 Level Students of the University of Ibadan. Humanities and Social Sciences. Vol. 1, No. 3, 2013, pp. 101-107. doi: 10.11648/j.hss.20130103.14

\begin{abstract}
The English language is undoubtedly a force to be reckoned with in the polity called Nigeria. In fact, as shall be soon made clearer in this paper, the language has been accorded so much power that it has relegated many of the country's indigenous languages to the background; a linguistic situation that is commonly and generally referred to as linguistic imperialism(see Philipson 1992). Many parents are under the false assumption that the acquisiton of the language is the main (and most times the only) means of measuring a child's intelligence and how well a child is positioned to face future challenges in the country. Such parents, mostly the educated ones, therefore would desist from communicating with their children in their local languages, and sometimes frown at the efforts of such children to mumble some words of their local languages, for fear that its knowledge might affect their acquisition of the English language, hence their poor performance in the language as a subject in school. It is therefore not surprising to see such parents exposing their children to the language from day one after birth at the expense of their local languages. This work gives insights to the performance of children from English-oriented homes vis-a-vis their counterparts from indigeneous language-oriented homes in the English language, as it concludes that there is no significant difference in the performance of these two categories of children in the administered English language test. It therefore renders invalid the early start and the maximum exposure tenets in line with the position of Philipson (1992).
\end{abstract}

Keywords: Philipson, Tenets, English Language, Performance, Children, Nigeria

\section{Background to the Study}

Philipson's (1992) work on linguistic imperialism is a critique on the hegemonic position the English language assumes among the league of languages in the world. In fact, he described the situation as English linguistic imperialism. In his words, English linguistic imperialism is " the dominance of English asserted and maintained by the establishment and continuous reconstitution of structural and cultural inequalities between English and other languages". In the excerpt above, the word structural implies properties as institutions, financial allocations; while the word cultural refers to immaterial or perhaps ideological properties in terms of beliefs, attitudes and pedagogic principles or ideologies.

According to Philipson, these structural and cultural inequalities manifest in the continued allocation of more material resources to the English language at the expense of other languages and by extension, their speakers; hence the hegemonic position of the English language. This development results in linguisticism. Philipson listed out certain key tenets, put in place by the British Council, which have promoted the teaching and learning of English; what he later termed as being fallacious. These are :

a. English is best taught monolingually

b. The ideal teacher of English is a native speaker

c. The earlier English is taught, the better the results

d. The more English is taught, the better the results

e. If other languages are used much, standards of English will drop.

He tagged the tenets respectively as follows:

a. The monolingual fallacy

b. The native speaker fallacy

c. The early start fallacy

d. The maximum exposure fallacy

e. The subtractive fallacy.

For the purpose of this work, four of these (fallacious) 
tenets shall be examined:

Tenet 1: English is best taught monolingually (the monolingual fallacy)

This tenet holds that the English language as school subject should be entirely taught through the medium of English. In other words, its teaching should exclude every other language.

Tenet 2: The earlier English is taught, the better the results (Philipson's Tenet 3: The early start fallacy)

This tenet holds that a child should be exposed to the teaching of the English language as early as possible, so as to ensure the child's excellent performance in the language as a school subject and as a medium of purposeful communication in general.

Tenet 3: The more English is taught, the better the results (Philipson's Tenet 4: The maximum exposure fallacy)

This tenet holds that the more the English language is taught, the better the results. Infact, the tenet assumes that for students who are weak in English, the more the exposure to the teaching of the language, the better the results.

Tenet 4: If other languages are used much, standards of English will drop (Philipson's Tenet 5: The subtractive fallacy)

The tenet holds that the standards of English are bound to drop if other languages are used as much as the language. Perhaps, this tenet represents, particularly, the fear many educated parents have which informs their exclusive use of the English language in communicating with their children, and which also manifests in the enrolment of their children in "English-speaking" schools where they could effortlessly acquire unequalled mastery of English.

\subsection{The Linguistic Situation in Nigeria}

Nigeria is a linguistically complex country. Owing to its multilingual nature, the linguistic situation in Nigeria could be described as that of dominant and dominated languages of different degrees of domination. The number of languages spoken in Nigeria cannot be given with precision because scholars tend to differ in their opinions about this. The highest figure so far given is 500 (see Hansford, et al, 1975; Crozier and Blench, 1992; Egbokhare, 2004). In some areas of Nigeria, ethnic groups speak more than one language. The official language of Nigeria, English, the former colonial language, has been chosen to facilitate the cultural and linguistic unity of the country. The major languages spoken in Nigeria are Hausa, Igbo, Yoruba. Even though most ethnic groups prefer to communicate in their own languages, English, being the official language, is widely used for education, business transactions and for official purposes. English has assumed a hegemonic status because through its official, instrumental and "integrative functions", it dominates the three major Nigerian languages, which in turn dominate the array of minor and minority languages in the country. The language dominates the indigenous languages in politics, education, judiciary, sports, and entertainment. It is a unifying force that binds educated speakers of the nation's indigenous languages together. In other words, the English language is a veritable tool of communication among educated speakers of Nigerian indigenous languages.

English, however, remains an exclusive preserve of a small minority of the country's urban elite, and is not very much spoken in rural areas. With large percentage of Nigeria's populace in the rural areas, the major languages of communication in the country could at best remain as national languages, with the most widely spoken being Hausa, Igbo and Yoruba. Foreign minorities keep to their own languages besides English and/or major native languages as their second languages. The linguistic situation in Nigeria could then be described as a microcosm of the linguistic situation in Africa as a whole. Africa as a continent is a continent endowed with myriads of languages.

It is however worthy of note that the languages in Nigeria are not evenly distributed among the thirty-six states of the country (Kassal 2000). While some states covering large areas have only one language, e.g. Oyo State, some others covering relatively small areas have array of languages, e.g. Edo.

\subsection{The Place and Role of English in the Nigerian Educational System}

In spite of the 'serious' efforts by the Federal Government of Nigeria to promote the indigenous languages in the country, the English language remains a force to reckon with in virtually all the important domains in the country. The English language operates in Nigeria as the official language, the restricted lingua franca (among the elites). Banjo (1982) asserts that the English language first came to Nigeria in the middle of the sixteenth century, imported by the English sailors who came to displace the Portuguese who dominated trade on the West Coast of Africa. This hitherto resulted in English-based Pidgin which was the order of the day till the middle of the nineteenth century, when the Standard English began to be taught institutionally to Nigerians. English occupies a preeminent place in the Nigerian educational system. English is used mostly as the medium of instruction at all levels of education, as opposed to the recommendation that English should be used in the last three years of primary school education, following the 1969 National Curriculum Conference. As a result of this, the government of the country came up with a proposal of trilingual solution to the problem of adopting a national language policy by stipulating that "Each child should be encouraged to learn one of the three major languages other than his mothertongue"(Kassal 2000:10).

Literally, the policy expects a child to learn one of the major Nigerian languages apart from his/her mother-tongue. However, so far, this policy has not been effectively implemented. The reality of the present situation is that much premium is placed by the government of the country on the child's competence in the acquisition and mastery of the English language. Amazingly, many parents decidedly 
would send their wards to some acclaimed standard schools, with the view to making sure their wards acquire the English language "perfectly". Also, a credit-level pass in English at the O' Level examination is a minimum requirement for admission into most courses in the Nigerian universities, polytechnics, colleges of education and other post-secondary institutions of learning. Whereas, not so much emphasis is placed on passing a Nigerian language as a pre-condition to securing admission into Nigerian tertiary institutions, except on very rare occasions when an individual applies to study Linguistics or a Nigerian language.

Lack of competence in English however, on the part of a Nigerian child, is like a bad omen, as far as the educational system of the country is concerned. It means such a child might have to let go of his dreams and aspirations of having formal post-secondary education, because until he or she passes the English language at the O' level, there is no admission into a tertiary institution. In fact, it is now believed that to make headway in the Nigeria of today; one must have an "English head".

\subsection{Attitudes of Nigerians towards the English Language}

There are three angles to attitude towards language. Attitudes could be positive, negative or ambivalent (indifferent), and attitudes could be informed by a number of factors as history, politics, economy, education; social and religion, among others (Baker, 2002 cf. Folarin, 2008).

With respect to language attitude in the Nigerian context, Bamgbose (1973 cf. Folarin 2008) describes the status of Nigerian languages in terms of: dominant - (English), deprived - (the most recognized of the three major languages- Hausa, Igbo and Yoruba), and endangered- (the other minority languages). Adegbija (1994) and Igboanusi and Peter (2005) equally observe that Nigerians (with a degree of exception of the Hausa) have positive attitude towards the English language than they have towards their mother tongues. This view is further reinforced by Afolayan (1999:83 cf. Folarin, 2008) who says "As a colonial people, Nigerians hold English in great awe. They overrate English that literacy in English is considered the only mark of being an elevated person". For Nigerians, science and technology are not within the reach of any individual who fails to have good mastery of the English language. Perhaps, this explains why the language has been regarded as being politically neutral for adoption by people. The language is obviously the language of politics in Nigeria.

Many parents especially the elite send their wards to feepaying primary schools where the medium of instruction is English. This is predicated on the belief that the earlier a child begins learning in English, the higher his chances of better mastery of the language. This will ultimately guarantee a good job. Some parents even go as far as preventing their children from speaking their native language at home even though they speak the same language.
Adegbija (1994) and Oyetade (2001) have attributed these positive attitudes towards English to a number of factors. Some of these are the colonial activities of the implantation of English in Nigeria and the continued status and roles assigned to the language in the country.

\subsection{The Problems of Learning the English Language in Nigerian Schools}

The rising influence of the English language in Nigeria, especially in the educational sector, has not been without certain challenges. According to Mckay (1965), "a child learning his mother tongue faces a problematic situation, whereas learning a second language is like fighting a battle". One of the many challenges associated with the teaching of the English language in Nigeria is the problem of lack of competent teachers. It has been observed of some schools in the country that people who do not have any qualification or related ones to teach the language have been saddled with the responsibility of teaching the language. This no doubt has posed a great challenge to proper mastery of the language by some learners, especially school students.

The size of class and its setting is another factor that has been observed not to have so much favoured the learning of the language in Nigeria. This is in line with Orisawayi's (1985) quoted from Adelabu (2006) view that a large class is a constraint on the teacher's plan for the verbal performance of the learners.

Another problem is linguistic interference. This is a common problem with second language learners. For instance, most students learning the English language as a second language are usually faced with the problem of transliteration ; bringing the sounds of their mother tongue to the production of English words. For instance, it is commonplace to hear Yoruba speakers of the English language to produce /d/ in place of / / in the language. Also, there is the problem of direct translation from mother tongue to the English language. Little wonder, one comes across such expression as "I will slap your face" among Nigerian speakers of the language.

\section{Methodology}

Due to the nature of this work, we employed both quantitative and qualitative research methodologies in our data collection and analysis. The subjects were selected undergraduate students of the Faculties of Veterinary Medicine and Arts, the Social Sciences and Engineering/Technology of the University of Ibadan were used as subjects. This, we believed, would give us campus spread data that would represent the main divisions of the disciplines in tertiary institution - Humanities and Sciences. Out of the over three hundred students among whom the questionnaires were initially distributed, one hundred and fifty-eight students were used as subjects in this research work. These were those whose responses in the questionnaires distributed were considered suitable for this 
work. Tests were administered to the subjects on the English language via questionnaires. The comprehension, writing and communication skills of the subject were tested.

Afterwards, we used statistical procedures and tests like graphs, T-test.We used Statistical Package for the Social Sciences software for data analysis.

\subsection{Demographic Information of our Subjects}

The following tables and pie charts show the demographic information of our subjects:

Table 1. SEX

\begin{tabular}{lllll}
\hline & Frequency & Percent & $\begin{array}{l}\text { Valid } \\
\text { Percent }\end{array}$ & $\begin{array}{l}\text { Cumulative } \\
\text { Percent }\end{array}$ \\
\hline Valid MALE & 84 & 53.2 & 53.2 & 53.2 \\
FEMALE & 74 & 46.8 & 46.8 & 46.8 \\
TOTAL & 158 & 100.0 & 100.0 & 100.0 \\
\hline
\end{tabular}

The table above shows the statistical distribution of our subjects with respect to their sex. Out of the 158 students used in this work, 84 are males constituting $53.2 \%$ of the total number of the subjects, while the females are 74 constituting $46.8 \%$ of the total number. This distribution gives us a fair representation of the two sexes used in the work

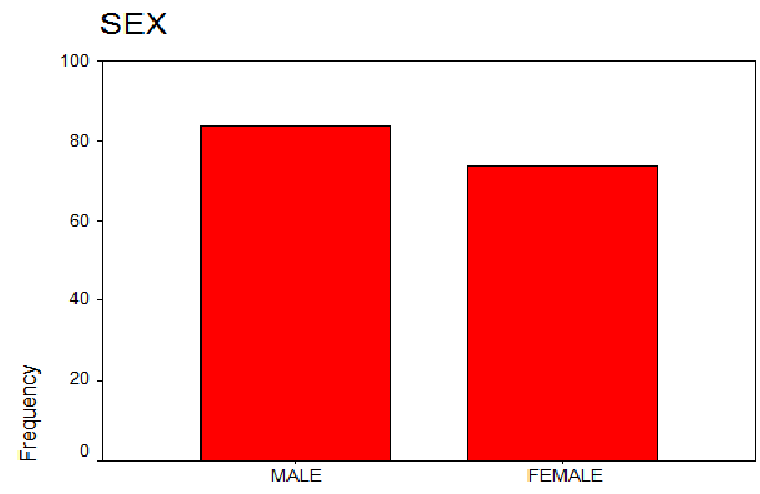

SEX

Table 2. Age of respondents

\begin{tabular}{lllll}
\hline & Frequency & Percent & $\begin{array}{l}\text { Valid } \\
\text { Percent }\end{array}$ & $\begin{array}{l}\text { Cumulative } \\
\text { Percent }\end{array}$ \\
\hline Valid 15-20 YRS & 115 & 72.8 & 72.8 & 72.8 \\
21-25 YRS & 43 & 27.2 & 27.2 & 27.2 \\
TOTAL & 158 & 100.0 & 100.0 & 100.0 \\
\hline
\end{tabular}

From this table, it is obvious that 115 students equivalent to $72.8 \%$ of our subjects are between the ages of 15 and 20 while 43 respondents corresponding to $27.2 \%$ are between the ages of 21 and 25.This further shows that majority of the 100 level students in the university are between the ages of 15 and 20.

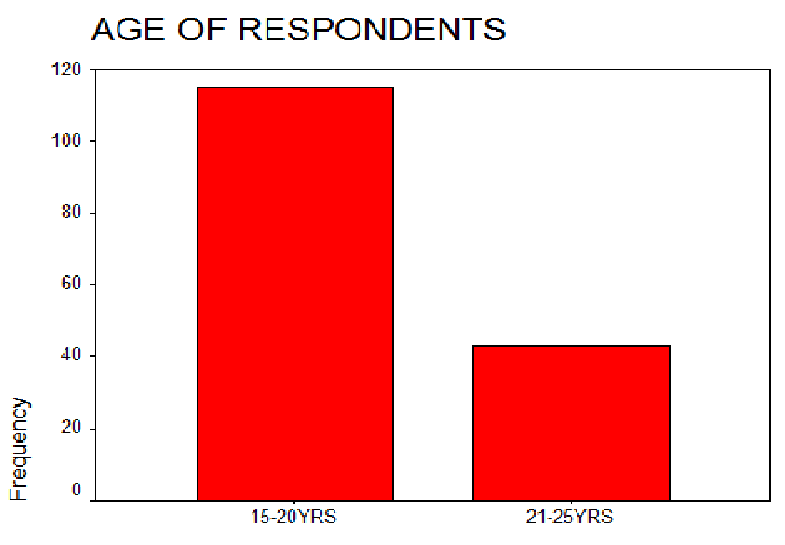

AGE OF RESPONDENTS

Table 3. Father's Highest Level of Qualification

\begin{tabular}{lllll}
\hline & Frequency & Percent & $\begin{array}{l}\text { Valid } \\
\text { Percent }\end{array}$ & $\begin{array}{l}\text { Cumulative } \\
\text { Percent }\end{array}$ \\
\hline Valid Elite & 67 & 42.4 & 42.4 & 42.4 \\
Semi-Elite & 37 & 23.4 & 23.4 & 23.4 \\
Non-Elite & 54 & 34.2 & 34.2 & 34.2 \\
Total & 158 & 100.0 & 100.0 & 100.0 \\
\hline
\end{tabular}

In this work, as shown in the table above, 67 (42.4\%) of our subjects are students from elite homes, 37 (23.4\%) are from semi-elite parents; while $54(34.2 \%)$ are from nonelite homes (based on our criteria for classification: father's academic qualification).

\section{FATHER'S HIGHEST LEVEL OF QUALIFICATION}

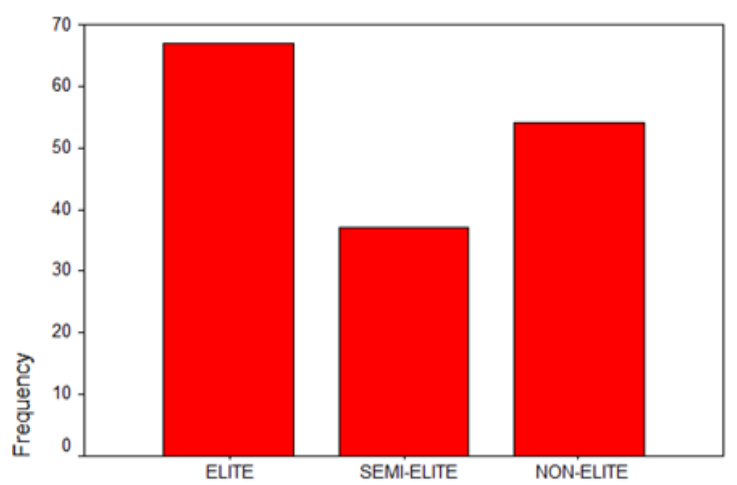

FATHER'S HIGHEST LEVEL OF QUALIFICATION

Table 4. Kind of Primary Schools Attended

\begin{tabular}{lllll}
\hline & Frequency & Percent & $\begin{array}{l}\text { Valid } \\
\text { Percent }\end{array}$ & $\begin{array}{l}\text { Cumulative } \\
\text { Percent }\end{array}$ \\
\hline Valid Public & 22 & 13.9 & 13.9 & 13.9 \\
Private & 136 & 86.1 & 86.1 & 86.1 \\
Total & 158 & 100.0 & 100.0 & 100.0 \\
\hline
\end{tabular}

This table is a graphic demonstration of the attitude of parents towards Government-owned schools in the country. Evaluating the mothers' social status on the basis of the 
fathers' social status, it is very clear from the table above that many parents would prefer to have their wards attend private schools, where it is believed, they can easily and "effortlessly" acquire the English language. This becomes obvious in the fact that 22 respondents equal to $13.9 \%$ of our subjects attended public primary school, while the remaining 136 respondents $86.1 \%$ attended private primary schools.

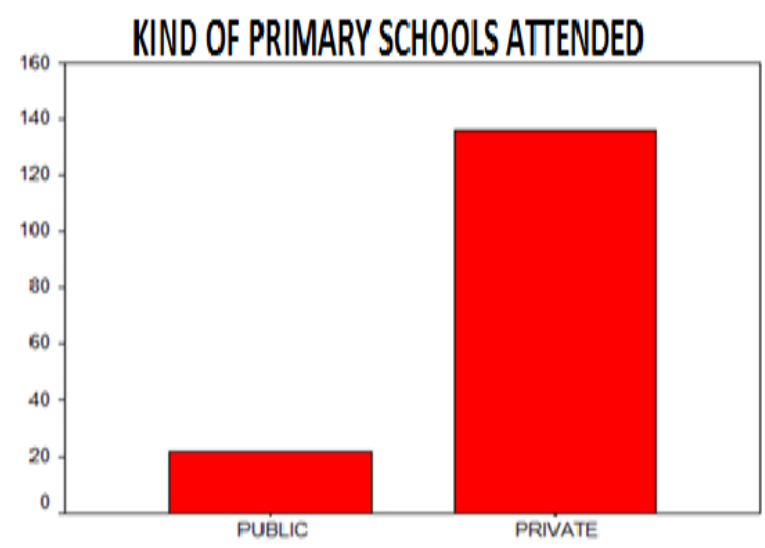

Table 5. Kind of Secondary Schools Attended

\begin{tabular}{lllll}
\hline & Frequency & Percent & $\begin{array}{l}\text { Valid } \\
\text { Percent }\end{array}$ & $\begin{array}{l}\text { Cumulative } \\
\text { Percent }\end{array}$ \\
\hline Valid Public & 47 & 29.7 & 29.7 & 29.7 \\
Private & 111 & 70.3 & 70.3 & 70.3 \\
Total & 158 & 100.0 & 100.0 & 100.0 \\
\hline
\end{tabular}

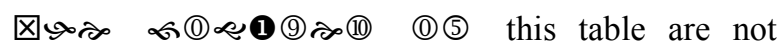
so much different from the ones we have in the previous one. The table still shows how much patronage private schools enjoy from the average citizen of the country, irrespective of their socio-economic status. The table reveals that 47 respondents corresponding to $29.7 \%$ of our subjects attended public secondary schools while 111 respodents $70.3 \%$ attended private secondary schools.

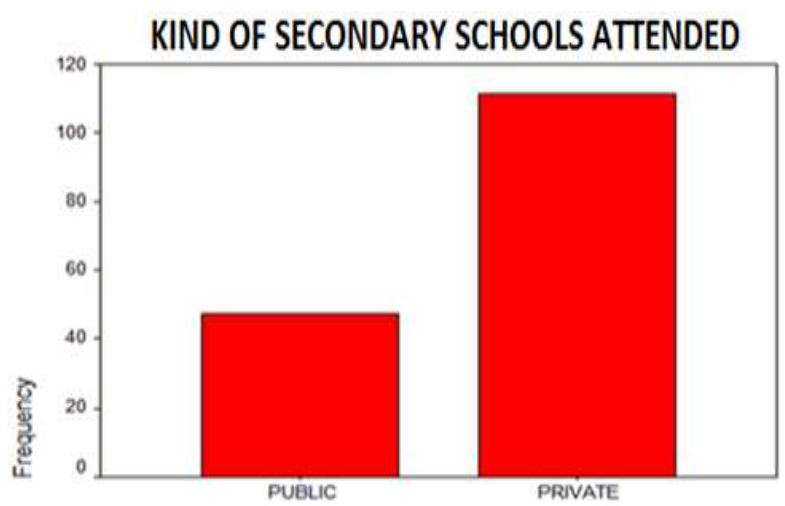

The tables and charts below further show the breakdown, giving the specific figures and percentages according to the classes to which our subjects were classified.
Table 6. Kind of Primary School Attended and Father's Highest Level of Qualification

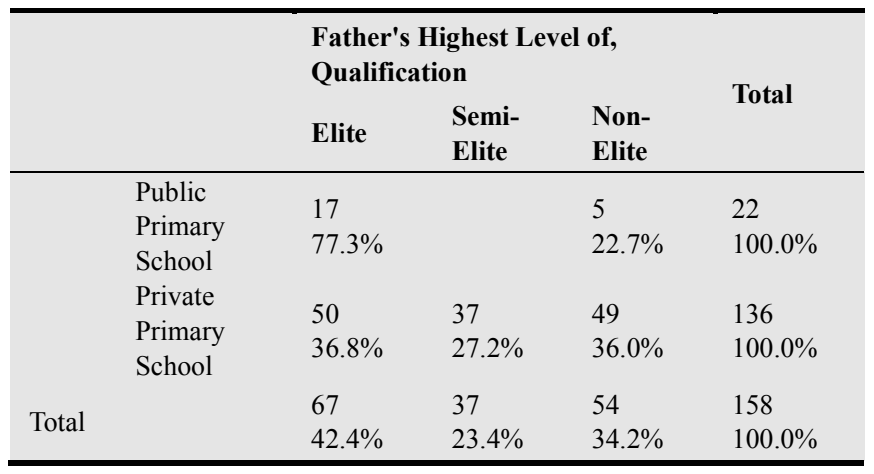

\section{KIND OF PRIMARY SCHOOLS ATTENDED}

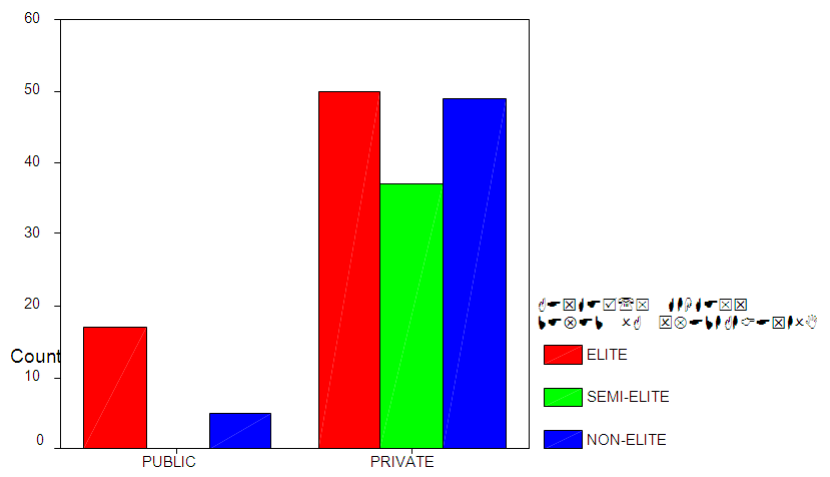

Table 7. Kind of Secondary Schools Attended and Father's Highest Level of Educational Qualification

\begin{tabular}{|c|c|c|c|c|c|}
\hline & & \multicolumn{3}{|c|}{$\begin{array}{l}\text { Father's Highest Level of, } \\
\text { Qualification }\end{array}$} & \multirow{2}{*}{ Total } \\
\hline & & Elite & $\begin{array}{l}\text { Semi- } \\
\text { Elite }\end{array}$ & $\begin{array}{l}\text { Non- } \\
\text { Elite }\end{array}$ & \\
\hline & \multirow{4}{*}{$\begin{array}{l}\text { Public } \\
\text { Primary } \\
\text { School } \\
\text { Private } \\
\text { Primary } \\
\text { School }\end{array}$} & 10 & 28 & 9 & 47 \\
\hline & & $21.3 \%$ & $59.6 \%$ & $19.1 \%$ & $100.0 \%$ \\
\hline & & 57 & 9 & 45 & 111 \\
\hline & & $51.4 \%$ & $8.1 \%$ & $40.5 \%$ & $100.0 \%$ \\
\hline \multirow{2}{*}{ Total } & & 67 & 37 & 54 & 158 \\
\hline & & $42.4 \%$ & $23.4 \%$ & $34.2 \%$ & $100.0 \%$ \\
\hline
\end{tabular}

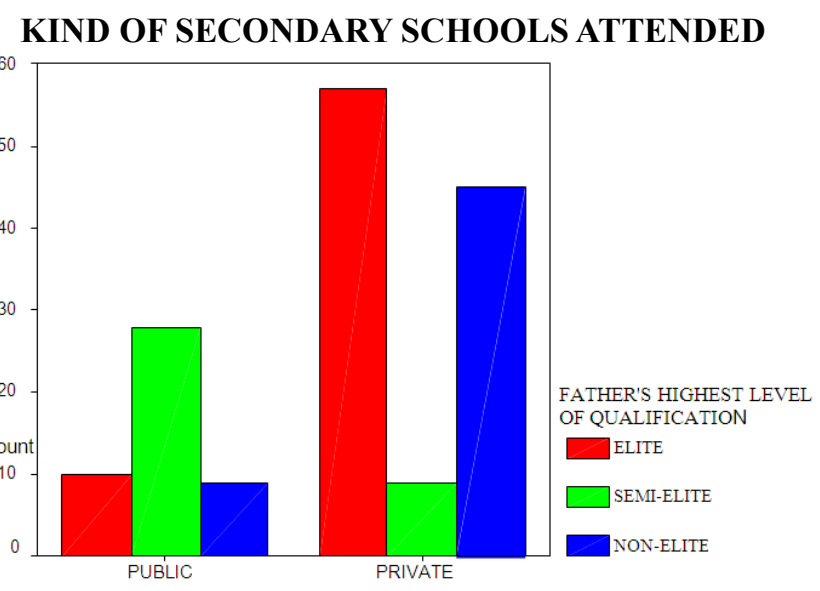


Table 8. First Contact with English

\begin{tabular}{|c|c|c|c|c|c|}
\hline & & \multicolumn{3}{|c|}{$\begin{array}{l}\text { Father's Highest Level of } \\
\text { Qualification }\end{array}$} & \multirow{2}{*}{ Total } \\
\hline & & Elite & Semi-Elite & Non-Elite & \\
\hline & Home & $\begin{array}{l}53 \\
434 . \%\end{array}$ & $\begin{array}{l}32 \\
26.2 \%\end{array}$ & $\begin{array}{l}37 \\
30.3 \%\end{array}$ & $\begin{array}{l}122 \\
100.0 \%\end{array}$ \\
\hline & School & $\begin{array}{l}14 \\
38.9 \%\end{array}$ & $\begin{array}{l}5 \\
13.9 \%\end{array}$ & $\begin{array}{l}17 \\
47.2 \%\end{array}$ & $\begin{array}{l}36 \\
100.0 \%\end{array}$ \\
\hline Total & & $\begin{array}{l}67 \\
42.4 \%\end{array}$ & $\begin{array}{l}37 \\
23.4 \%\end{array}$ & $\begin{array}{l}54 \\
34.2 \%\end{array}$ & $\begin{array}{l}158 \\
100.0 \%\end{array}$ \\
\hline
\end{tabular}

This table graphically illustrates the distribution of our subjects with respect to where they first had contact with the English language. As expected, a greater percentage of our subjects from elite homes had contact with the English language at home before starting school. 53 students equivalent to $43.4 \%$ of our subjects from elite homes had contact with the English language before school, and just 14 students equal to $38.9 \%$ of them had their first contact with the English language in school. Equally from the table, we can observe that 32 students corresponding to $26.2 \%$ of our subjects from semi-elite homes had contact with the English language at home before starting school, while 5 students equivalent to $13.9 \%$ of them first had access to the English language in school. $37(30.3 \%)$ of our subjects from non-elite homes had contact with the English language at home and 17 students equal to $47 \%$ of them had contact with the language in school. From the table, it is crystal clear that the highest percentage of our subjects that had contact with English before school were from elite homes, while the highest percentage of our subjects who first had access to English in school were from non-elite homes.

Table 9. T-test (n-2) Group Statistics

\begin{tabular}{llllll}
\hline & $\begin{array}{l}\text { First } \\
\text { Contact } \\
\text { With } \\
\text { English }\end{array}$ & N & Mean & $\begin{array}{l}\text { Std. } \\
\text { Deviation }\end{array}$ & $\begin{array}{l}\text { Std. } \\
\text { Error } \\
\text { Mean }\end{array}$ \\
\hline $\begin{array}{l}\text { Linguistic } \\
\text { Ability And } \\
\text { Performance }\end{array}$ & Home & 122 & 54.2951 & 8.7864 & .7955 \\
\hline
\end{tabular}

We used t-test to examine whether or not the place of first contact with English has any statistically significant influence on the performance of the subjects in the administered test. From the table above, it becomes clear that there is no statistically significant difference in the linguistic ability and performance of the students who first had contact with English at home before starting school and those who did not until they began school. Their mean scores are 54.30 and 53.11 respectively. The t-test difference is $\mathrm{n}-2 \quad 158-2=156(.650) ; \mathrm{P}>.05 . \mathrm{ns}$ (non significant). This finding somewhat refutes the widely held opinions about early and maximum exposure to the English language without consideration for one's indigenous language(s).

\section{Conclusion}

The results of our findings apparently show that the last three tenets, that is,

- The earlier English is taught, the better the results

- The more English is taught, the better the results

- If other languages are used much, standards of English will drop

put forward by the British Council (advocating the promotion of English) are not valid, and as such considered fallacious in agreement with the position of Philipson (1992). This cannot but be in view of the fact that we observed there is no statistically significant difference between the performance of our subjects who had had contact with the English language before they started school ( the earlier the English is taught, the better the results, if other languages are used much, the standards of English will drop) and those who did not have (much) contact with the language until they began school. If this were to be valid, one should have seen an obvious gap in the performances of these two groups of students in the administered test. At worst, if any of these three abovelisted rejected tenets is to be considered for adoption, definitely, the last one will not be considered in view of the result of our analysis.

We therefore advocate the use of other languages alongside the language in parents-children communication to prevent the breeding of monolinguals, who are not even competent in the so-called "English language" they claimed to be monolingual in.

\section{References}

[1] Adelabu, S,T. 2006. The impact of the English language on the performance secondary school students: a case study of some selected secondary schools in Ibadan. An M.A. Project. Department of Linguistics and African Languages . University of Ibadan

[2] Adegbija, E.1994. Language attitude in sub-saharan African. A sociolinguistic overview. Clevedon, Multilingual matters.

[3] Brosnahan, L. 1963. Some historical case of language imposition in Spencer, J. (ed.) Language in Africa. Cambridge: Cambridge University Press

[4] Crozier, D. and Roger Blench (1992). An Index of Nigerian Languages. Texas and Abuja: SIL and the NERDC.

[5] Egbokhare, Francis. (2004). 'Language and Politics in Nigeria' pp. 507-522, in eds. Owolabi, Kola and A. Dasylva. Forms and Functions of English and Indigenous Languages in Nigeria. A Festschrift in Honour of Ayo Banjo. Ibadan: Group Publishers.

[6] Folarin, A.T. 2008. Attitude of secondary school students towards English and Yoruba language: a case study of public and private secondary schools in Ibadan. An M.A Project, Department of Linguistics and African Languages. University of Ibadan 
[7] Hansford, K.J. et al (1976). An Index of Nigerian Languages. Studies in Nigerian Languages 5. Summer Institute of Linguistics, Jos and Accra: Summer Institute of Linguistics.

[8] Igboanusi, H and Peter, L. 2005. Languages in competition: the struggle for supremacy among Nigeria's major languages, English and Pidgin. Frankfurtan Main: Peter Lang, Europaischer Verlag der Wissenshaffen

[9] Kassal,B. 2000. An application of the Bernstein' hypothesis to the study of Yoruba-English bilingual acquisition and learning in selected secondary schools in Ogun state. A P.hD.
Thesis. Department of Linguistics and African Languages . University of Ibadan

[10] Mckay,W.F. 1965. Language teaching analysis. London, Longman, Green \& Co

[11] Oyetade, S.O. 2001. Attitude to foreign languages and indigenous language use in Nigeria in Igboanusi, H. (ed) Language attitude and language conflict in West Africa. Ibadan

[12] Philipson, R.H.L 1992. Linguistic imperialism. Oxford: Oxford University Press. 